\title{
INTERACTION PATTERNS IN ENGLISH AS FOREIGN LANGUAGE CLASSROOM AT LOWER SECONDARY SCHOOLS
}

\author{
Hanna Sundari \\ English Education Department, Universitas Indraprasta PGRI Jakarta, Indonesia \\ E-mail: hanna.sundari@gmail.com \\ Zainal Rafli \\ Language Education, Postgraduate of Universitas Negeri Jakarta, Indonesia \\ E-mail: zainal.rafli@gmail.com \\ Sakura Ridwan \\ Language Education, Postgraduate of Universitas Negeri Jakarta, Indonesia \\ E-mail: sakura.hattamarrasjid@gmail.com
}

\begin{abstract}
APA Citation: Sundari, H., Rafli, Z. \& Ridwan, S. (2017). Interaction patterns in English as foreign language classroom at lower secondary schools. English Review: Journal of English Education, 6(1), 99-108. DOI: 10.25134/erjee.v6i1.775.
\end{abstract}

Received: 29-08-2017

Accepted: 31-10-2017

Published: 01-12-2017

\begin{abstract}
Interaction plays an important role in language learning process in classroom setting. This present study aims at investigating the patterns used in classroom interaction by English lower secondary teachers. Using qualitative approach, this study was carried out in eight lower secondary schools (SMP) in Jakarta. Moreover, twenty English language experienced teachers with three to thirty-six years of teaching experiences were recruited as participants. Interviews, classroom observations/recording and focus-group discussion were instruments to collect data. For analyzing the data, qualitative data analysis was selected in developing categories and sub-categories of the data. The findings showed that the teachers apply at least three identified interactional patterns in EFL classroom in which modify the IRF structure. Teachers initiate interaction to the entire class (T-whole class interaction) by giving questions and instruction. Then, they also point out one specific student to answer the question or do the required task (Teacher fronted student interaction). In addition, teachers set the classroom activity to make the students interact each other (student-student interaction). Moreover, the student responses and other interactional features identified in language classroom are also discussed.
\end{abstract}

Keywords: interaction patterns, EFL classrooms, secondary school

\section{INTRODUCTION}

Illustration: Once in language class, a language teacher calls name and gives questions to the students sitting in the front row; other time, she points out one student at the back seat. Otherwise, she throws them away for those who can answer freely. In one time, she corrects the error made by the student by yelling "is it correct?". In another time, she just ignores it. At one lesson, she sets the class in individual task; next lesson, the students are grouped in 3 or 4 to do the activity.

Language learning can be taken place in and through interaction with others in various social contexts. In sociocultural theory views on language learning, the major aspects of language is related to and formed by the ways in which the people interact with others in various communicative contexts; therefore, in learning language, interaction is not only as a learning facilitator but also primarily is as a resource for what to learn and how to learn (Thoms, 2012). In short, interaction can be viewed as both the tool and the object in which language used in interaction is the medium as well as the goal to be learned. Classrooms are one of social environment 
which language lesson could be complex. Language classrooms are complicated places where social events and social relationship between teacher as the knower and students as the learners may influence their social interaction and classroom practices as a part of process in language learning. Different from other social context, in language classrooms, language used is intentional and purposeful as Walsh (2011) states that discourse in the classroom has to follow the teacher's agenda. The delivered questions, correction and feedback by the teachers are set to help the students achieve language competences. Meanwhile, the students' responses are also to fulfill the task given.

In general, interaction is dual communication acts between two people or more that have implication among them. In short, interaction can be stated as action and reaction of two people. According to Brown (2007, p. 212), interaction is "collaboration of thought, feeling, or ideas between two people, resulting in a reciprocal effect on each other". Reciprocity as the implication indicates that interaction involving both parties as active interactants instead of passive ones. In the pedagogy field, Allwright noted that a process of interaction is necessarily involved in a fruitful classroom pedagogy (Seedhouse \& Jenks, 2015). It can be stated that successful pedagogical process in the classroom proceeds by successful interaction management.

In the English language teaching (ELT) enterprise, interaction has a prominent role in language acquisition and learning process. In the view of social interaction, child acquires language through social interaction with parent in her first life. Interaction is important in natural language acquisition (Choudhury, 2005). Moreover, parental language as a model influences language complexity acquired by the child now and years after (Sundari, 2016). Meanwhile, in the classroom setting, interaction between teacher as a competent person and students as learners, or student-student interaction, leads them to get competences in knowing and using the language in the classroom. in the other words, language learning is mostly interactive process (Richards \& Lockhart, 2007). Classroom interaction is mostly in the form of conversational exchanges or dialogue between teacher and students in target language. Markee and Kasper (2004) cited by Kharaghani (2013, p. 859) wrote that "interaction is a form of institutional talk which is locally managed but cooperatively constructed speech exchange system".

Concerning to interaction in language classroom, the moves are mostly starting with teacher initiates the communication by asking the students questions to get them involved to the lesson. After that, the students are required to respond the questions. The last is feedback as immediate evaluation or correction for students' responses (Rustandi \& Mubarok, 2017). The pattern of interaction in language classroom, postulated by Sinclair and Coulthard (1975) cited by Murray \& Christison (2011), is then called IRF (initiation-response-feedback) exchange. Moreover, Hall (2003) exemplified this basic unit of classroom interaction in which involves the teacher, as expert, eliciting information (initiation) from students to confirm if they understand the materials by asking questions. Then, the students are expected to deliver targeted responses (response). After that, the teacher examines the student's response by giving feedback with such particular phrases as "Good", "well done", "No, that's not correct." In addition, this pattern of classroom interaction as two-way a process between interactants in the learning process is depicted in Figure 1 (Dagarin, 2004; Rustandi, 2013 in Rustandi \& Mubarok, 2017, p. 241) depicted interaction in two-way process between participants in the learning process as seen in Figure 1.

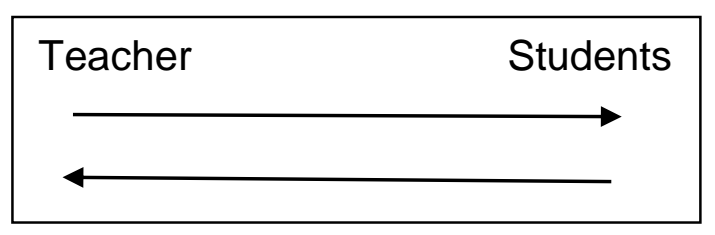

Figure 1. Classroom Interaction Pattern 
Furthermore, the teachers have also a significant role in managing classroom communication. Based on who communicates with whom, Dagarin (2004, p. 129) formulated the four forms of interaction in the following: teacher-learners, teacher - a group of learners, learner-learner, learners-learners. In these forms of interaction, the teachers alternately change their roles as a controller, language model, guide, evaluator, and advisor in pair-work or group-work types of communication in the classroom. In addition to Dagarin, Malamah-Thomas (1987 cited by (Nisa, 2014) propose seven types of classroom interaction: teacher - whole class, teacher - individual student, teacher- a group of students, student - teacher, student-student, student - a group of students. A variety of interactional patterns in language classroom may affect the language learning process as well as the development of language proficiency.

In classroom interaction, the teacher initiates communication by asking a question. Teacher questions are mostly in display question in which the answer is already known to the teacher (Choudhury, 2005; Farahian \& Rezaee, 2012; Petek, 2013; Pujiastuti, 2013; Suryati, 2015). Even though teacher gives opportunities to students to involve verbally in the class in many ways, not all students participate verbally and actively in classroom communication by giving response for some reasons. Factors in and outside the classroom may affect how the classroom discourse occurs. What kind of questions teachers deliver and how much teachers talk during the lesson may eventually influence how the students acquire and develop their language progress (Hermanto, 2015; Seedhouse \& Jenks, 2015). Moreover, Cultural background and personality may cause the student reticence (Choudhury, 2005, p. 78). Besides, teacher looks more focusing on the students sitting in the front, middle row, as illustrated by Richards \& Lockhart (2007, p. 139-140). Figure 2 shows when the teacher stands in the front of the class during the lesson and deliver the questions to all students. However, students in edge row sound no responses.

Figure 2. Teacher interaction in the classroom

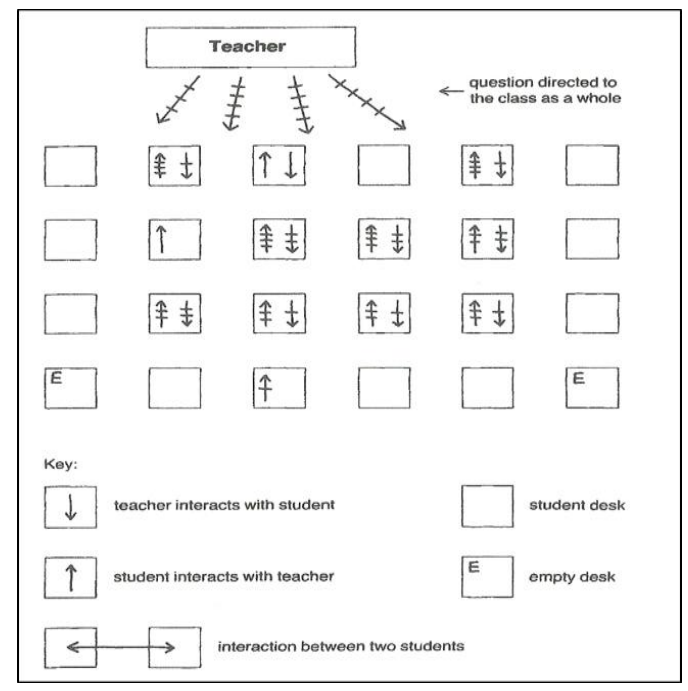

The study of interaction in language classroom and its implication for language learning have been widely conducted in the field of English language teaching (ELT). Applying discourse analysis approach, Rashidi \& Rafieerad (2010) investigated interaction patterns and its effect on gender in
Shiraz University Iran. They concluded that the interaction patterns between participants vary with the participants making use of variety of discourse acts and male students are willing to be more interactive than female in language classroom. In 2013, Nasruloh conducted a study to 30 elementary students 
in Bandung and reported that teacher dominates the lesson verbally by giving direction, lecturing, and criticizing or justifying authority. The students seem to have great opportunity to talk; however, they keep restricted in some ways. By analyzing classroom interaction in EFL speaking class, Nisa (2014) concluded that the teachers facilitate the student-fronted speaking activities such as class discussion, presentation, simulation and communication games, yet, in fact, students' first language during the lessons was often used. Furthermore, Rustandi and Mubarok (2017)'s study on classroom interaction in EFL speaking class at university sum up that IRF pattern is fully implemented in the class. Teacher initiates the interaction by giving questions, soliciting information, and identifying next students' turn. Besides, responses from the students are dominance; yet they depend on the content materials and teacher strategies in provoking students. Related to study on questioning strategies as one of interaction features, Rido (2017) also reported that teachers in vocational English classrooms nominated specific student to answer questions, asked questions to the entire class, and repeated questions when there were no response.

On the other side, the study examining the interaction pattern in English as foreign language classroom at lower secondary schools based on teacher's perspectives is still rare and restricted. Present research on second and foreign language learning from sociocultural perspective mostly come from university-level classrooms; meanwhile, only a little is known to explore what occurs in elementary or secondary schools (Hall, 2003). Indeed, lower secondary students are mostly learning English as beginner; at the same time, they will take English national examination to continue their study. Interaction and communication in the classroom, as the heart of language learning become necessary to understand and the constraints have to be solved. The way teacher interacts with the students determines the way student respond it; at the end, it influences how proficient the students are to communicate in target language. Classroom interaction in the early years of learning process can be a foundation to the next language development. The fully understanding of its process becomes necessary and helpful. To devote to these views, this study addresses to the following research questions: what patterns are used in classroom interaction by English lower secondary teachers and why they use the patterns.

\section{METHOD}

This present study, as a part of research in classroom interaction of EFL setting, was carried out by qualitative research approach to investigate the interaction patterns in English as foreign language classrooms. To accommodate the research objective, twenty English language experienced teachers were recruited as participants from eight lower secondary schools (SMP) in Jakarta. They were three male and seventeen female teachers with three to thirty-six years of teaching experiences.

For collecting data, classroom observations/recordings, semi-structured interviews and focus-group discussions with the teachers were instruments. 10.5 hours of classroom observation/recording conducted only with teacher's approval was to identify specific patterns in oral communication in the classroom. Flint protocol analysis of classroom observation (Moskowitz, in Brown, 2007) was applied to capture interactional features completed by memo writings. Meanwhile, interviews and FGD were to elicit teachers' reasons, opinion and perspectives of their interaction practices in the classroom. The interviews and FGD then were transcribed verbatim and analyzed.

After that, to analyze the obtained data, the researcher followed the steps in opencoding, developing categories, and triangulating data. At first, the data were carefully labeled and named into several categories. Secondly, the categories were then divided into sub-categories. At last, the categories and sub-categories found were triangulated with the interview transcript and memo writings. 


\section{RESULTS AND DISCUSSION}

This study is an attempt to identify interaction patterns in English as foreign language classrooms at lower secondary schools and discover the reasons why the patterns applied from the perspectives of English language experienced teachers in Jakarta. The findings of the study will be presented in combination of interactional patterns and several causes of selected patterns from teachers' perspectives.

From classroom

observations/recordings and interviews added by focus-group discussion, it is resulting in several interactional patterns in which is grounded by IRF structure. Modified IRF structures can be apparent when teachers initiate the interaction in several ways, students respond in several ways; however, feedback by the teachers is not always available. To not strictly follow the IRF structure, this finding is consistent to the study by Rashidi \& Rafieerad (2010) in which not only teachers but students initiate conversation exchange.

Furthermore, question and answer routine are mostly emerged as the most dominated pattern. Asking question is the most effective tool to initiate interaction and take immediate verbal response.

Mrs. Lil starts the interaction with the students by delivering questions Who likes sport? Who usually plays badminton? (CO-08).

Teacher asks who is absent today and divides the class into groups then asks you choose the group or I choose the group? (CO-04).

After 5 minutes, the teacher asks questions related to the poem, who writes the poem? What is the content of the poem? (Co-02). Then, teacher reviews previous lesson by asking question, what have we learned yesterday? (CO-03).

This result may support the study by Rido (2017) and Suryati (2015). They found English lessons were dominated by question and answer routine and the most popular interaction strategy is asking display question. Meanwhile, giving directions or instruction is also apparently salient feature in initiating interaction in language classroom. By giving directions, the students are expected to do the required activity as response.

Teacher greets the students and gives some instructions of how to do the test. (CO-01).

Teacher shows a poem on the LCD screen and directs the students to read it silently. (CO-02).

Then, teacher gives instructions what to do with slow pace. (CO-03).

Teaching can be said as talking in the classroom setting. Teachers use speech to direct, lead, guide, instruct and persuade the students to act many things as well as to make them silent (Robinson, 2005). By giving instructions, teachers act as controller and manager to manage the classroom. On the other side, the students listen and do the required tasks. The teachers are the subject of the learning process; while students are mere object (Robinson, 2005). It depicts the fact that the relationship between teacher and students in the classroom is asymmetrical (Consolo, 2006; Walsh, 2011).

The first pattern identified from the data is teacher- whole class interaction. It is when the teachers ask questions, direct the students, and communicate to all students in the classroom without nominating one specific student. The teacher lets any student to response. Then, the students will yell and shout in responding teacher questions.

Teacher asks at least four times to the class: do you know television? Do you have television. (CO-O1).

Again, teacher provides text about television on the LCD screen, asks the students to memorize it, and deliver several questions. Then, she repeatedly asks "finish?" until she hears "yes" sound loudly. (CO-O2).

Moreover, teacher give instructions what to do with slow pace. All instructions are in English... Teacher reads the text a loud and gives more examples on the board. (CO-03).

Then, teacher directs the students to count 1-5... She explains how to do the whispering games. When the class look noisy and messy, teacher repeatedly shout "but" to get students' attention. Again, 
she asks a question: do you know what to do? (CO-04).

After the video was finished, the teacher suddenly asked question what are they, the students were just in silence with no response. (CO-09).

Teacher-students (whole-class) interaction, according to Harmer (2007), is the most widely used in various culture. This pattern is beneficial in giving long explanation and evaluating language progress because teachers easily control and handily manage the classroom. Teacher speaking to the whole class is also revealed in study by Nisa (2014) in which teachers use this mode in opening the lesson, giving feedback, and presenting information.

The interactional pattern from EFL classroom is teacher-student fronted interaction. In the front of the class, as the conventional standing position, the teachers sometimes choose to point out one student to answer the questions in purposes.

Furthermore, they also walk around the class and converse to certain student individually or in group for some reasons.

The teacher walks around the class and comes to each student one by one to monitor their activities. (CO-04).

Teacher displays some pictures of sport and its instruments on the LCD screen and asks the students to determine the names by pointing them out. (CO-08).

Teacher calls several names to open their notebook. (CO-09).

Rarely sitting in her desk, Mrs. An keeps walking around to have a chat with the students. (CO-11).

Sometimes, the teacher is calling students names, such as Ryan, Arif, to hear their answers. (CO-12).

After the video is finished, the teacher asks the questions to certain students one by one: what do you like to do, Emma? What do you like to do, Naya? What do you like to do, Zahra? While approaching their desks. (CO-03).

The similar result also comes from the study Rido (2017, pp. 203-204). He wrote that nominating specific students to answer questions was a common practice by master teachers in the classroom. In addition to nominating specific student, teacher mobility is one of the interaction feature showed in the language classroom. Having finished giving directions, teachers walk around the class and come to each student or group. Monitor and evaluation of student's activity are the reasons as well as building rapport to the students.

Mrs. Rah approaches one student to monitor her activity. (CO-13).

$\mathrm{Mr}$. Am walks around one student to another, one group to another. (CO-10). Rarely sitting in her desk, Mrs. An keeps walking around to have a chat with the students. She gives feedback to the students by saying: $O K$, I see, it's $O K$. (CO-11).

The teacher approaches students' desks one by one, monitors their activities, gives more explanation, and responding student's questions. (CO-03).

Teachers move around the class is also stated in several research findings. Wachyudi, Srisudarso, and Miftakh (2015) reported that during the session, teachers stand and move around to make the lesson interesting. Teachers approach the students who looks confused on the topic or task given. Next, the similar result is also showed the study by Rido, Ibrahim, and Nambiar (2014). They wrote that teachers move around the class and approach the students when delivering questions and paying attention to student's response.

Another identified pattern in language classroom interaction is student-student interaction. While learning language in the classroom, teacher sometimes designs the classroom to make the student interact with other students. Some classroom activities are set to stimulate them as peer or speaking partners for classmates.

Speaking activities seem quite difficult, the students do in pair, ask likeldislike to other students sitting next to her diagonally, and record them on note. (CO-03).

In whispering horse games, the class is so noise. In group, students are competing to be the fastest and the rightest. (CO-04). Having continued the lesson, the teacher gets the students to do in group of 4-6.... 
The students then move the desk to make the group. (CO-10).

Mrs. An distributes worksheets to the students so that they do the activity in group. (CO-11).

Setting classroom activity in pair or in group brings advantages for both teachers and students. As Harmer (2007, pp. 116-117) stated, pair and group activity provide a plenty room and opportunities to use the language with peers; meanwhile individual activity stimulate autonomy and independence in learning language. Almost the same result is also apparent in research by Nisa (2014). On her study, pair work and group work are used to stimulate the use of language among students in speaking classes.

Concerning to the responses, the teachers are waiting expected responses either verbal or non-verbal in which are in accuracy, fluency, and acceptance in the line with the learning objectives. However, the students, in fact, as language learners, respond in several ways: in verbal, in action, and no response. Verbal responses are the most noticeable feature in language classroom. It primarily is for responding teacher questions.

Then, the students say it together with loud voice. (CO-01).

All students at once answer loudly the teacher question. (CO-08).

Beside verbal responses, the students also providing action or activity as required and directed by the teachers.

Some of the students stay calm and quite as taking the test; while, the others are discussing with their classmates. (CO-01).

The students are walking around the class and asking their classmates about the required expressions, and taking note. (CO-03).

Nonetheless, not all students give expected response. Because of some causes, they do not answer the questions, answer the questions with wrong answer, or do something else.

Students are allowed to add the answer or give other different opinions.

Nevertheless, no student arises. Teacher let any student to do question no. 4. Yet, no one comes forward to. (CO-02).

Mrs. Rah asks the students to do the exercises on the worksheet. Some of them are discussing; meanwhile, some others look confused and do something that is not instructed, such as drawing and keeping silent. (CO-13).

As the matter of the student response, Rustandi and Mubarok (2017) also reported that interaction in speaking class at university level, students are less initiative to start the conversation because of shyness and reluctance. These results may not be consistent to the research findings by Nisa (2014) that, beside student response and initiation, silence and confusion in interaction during speaking session are when the teacher wrote the materials and confusion occurred as more than one person talking. However, related to how students interact with and responses to teacher's communication in the classroom, it is also surprisingly identified that several students in particular situation initiates interaction with the teachers by asking questions or requesting something, though it does not frequently happen.

Students ask several questions related to content materials and vocabulary. (CW06).

During the lesson, the students often ask "mom, I don't understand about it" or "I'm confused, mom. Can you explain more?". Else, for those who have limited language, they say "mom, how...how..." to require more explanation. ( $\mathrm{CW}-10)$. Some of the students often asks about vocabulary, "Bapak, banyak bahasa Inggris nya apa, Pak?" (Sir, what is many in English?). (LO-10). One student yells "why is it advice instead of advise?"; then the teacher explains the differences among those two words. (LO-12).

One of the students says "another song, mom". Teacher accepts the student's request and finds another song to play before the lesson starts. (CO-03).

The interaction patterns in EFL classrooms can be schemed on figure 3 . 
Teacher-Students (whole-class) interaction is as one pattern in which teachers initiate interaction to entire class by giving questions or directions. Then, pattern two is teacher-confronted student interaction. Teacher starts interaction by nominating one specific student or students in group. Pattern three is when the teachers set the students in pair or group to make them to interact each other, called studentstudent interaction. These patterns add the types of classroom structures of interaction observed by Suryati (2015) at lower secondary schools in Malang, East Java. She wrote two types of classroom interaction: teacher fronted interaction and student-student interaction. The similar patterns of classroom interaction can be taken from the research by Nisa (2014). The types of classroom interaction during speaking activities are teacher-whole class, teacher-student, teacher-a group of students, studentteacher, student-student, and student whole class.

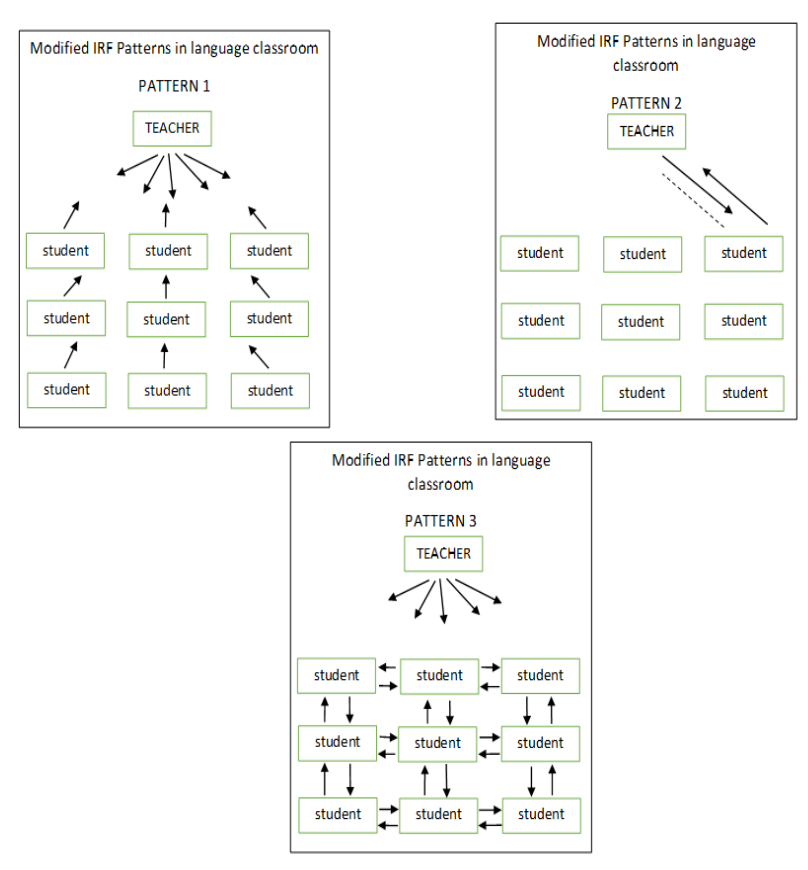

Figure 3. Interaction patterns in EFL lower secondary classrooms

Teaching is probably on the teacher's hand as controller who usually initiates the interaction in language classroom.

Nonetheless, teacher has several considerations underpinning her selection and preferences used in the classroom. Classroom interaction and dynamic result from teacher choices in classroom activity (Richards \& Lockhart, 2007). Based on the interviews, smooth and effective teaching process is the priority for teachers. To make each student speak, Mrs. Li prefers calling names and pointing the students out.

When they are responding, there is time I call by names or calling names. Else, when I deliver the question to entire class, no student responds or there are great responses with loud, shouted voices that make unclear noisy echo. I decide to select one by one. besides, I want them to produce much language. At this time, I will point out... (TW-02).

Calling names is not just random pick. Excellent students are more preferable because they can be a good language model for others. At this time, I will point out the excellent student to stimulate less student. (TW-02). Teacher delivers the questions to entire class; sometime she points out one student. Especially excellent student is selected as language model for other students. ( $\mathrm{CW}$ FGD-01).

For instance, one student looks competent at the discussed topic. Therefore, I point 
him out. Sometimes, he explains it in English or Indonesian. (TW-12).

Nominating specific students was also revealed in study by Rido (2017). He reported that teachers point out specific students to make proficient students help less proficient students. Moreover, this strategy is to make student more alert and attentive to the lesson as well as to give equal opportunity for each student to practice English.

\section{CONCLUSION}

This current study aims at describing the interaction patterns in EFL classroom at lower secondary schools and some reasons underpinned the pattern selection. When interacting and communicating with the students in the classroom, teachers do not strictly follow the IRF structure. They greet, ask, direct, and lead to the entire class, called teacher-whole-class interaction. To publicly communicate, the teachers feel more effective and saving time. Then, they also nominate and call one specific student, as teacher-fronted student interaction, to stimulate individual language production and evaluation as well as a good language model. At last, teachers set the classroom activity to make the student interact each other. Pair-work and group-work help the students communicate and improve their language.

Concerning to the interaction patterns in language classroom, the research found that at least three modified IRF structure. Firstly, teacher - whole class is as the most common pattern in the class, then students give various kinds of responses. The second pattern is teacher - individual student by nominating specific students; the student's response can be expected and targeted response, confusion or giving non-verbal response. The last, teachers also set the class in pair work or group work to build communication and interaction among students.

These research findings may not explicitly describe the importance and the quality of interaction in the EFL classroom; neither may these assess the teachers' interaction competences in language teaching. However, the results depict the teachers' roles in language classroom in foreign context. They play the prominent roles. They control the moves of lesson, they manage who talks, when and how much, and they also become student' speaking partners and language model.

\section{REFERENCES}

Brown, H. D. (2007). Teaching by principles: An interactive approach to language pedagogy. New York: Pearson Education.

Choudhury, S. (2005). Interaction in second language classrooms. BRAC University Journal, II(1), 77-82.

Consolo, D. A. (2006). Classroom oral interaction in foreign language lessons and implications for teacher development. Linguagem \& Ensino, 9(2), 33-55.

Dagarin, M. (2004). Classroom interaction and communication strategies in learning English as a foreign language. ELOPE: English Language Overseas Perspectives and Enquiries, 1(1-2), 127139. Retrieved from https://doi.org/10.4312/elope.1.1-2.127-139.

Farahian, M., \& Rezaee, M. (2012). A case study of an EFL teacher's type of questions: An investigation into classroom interaction. Procedia - Social and Behavioral Sciences, 47, 161-167. Retrieved from https://doi.org/10.1016/j.sbspro.2012.06.631.

Hall, G. (2011). Exploring English language teaching: Language in action. New York: Routledge.

Hall, J. K. (2003). Classroom interaction and language learning. Ilha Do Desterro, 44, 165-187.

Harmer, J. (2007). The practice of English language learning. Malaysia: Pearson Education Limited.

Hermanto, H. (2015). Understanding teacher talk to support students' communicative competence. Jurnal Sosial Humaniora, 8(2), 143-159.

Kharaghani, N. (2013). Patterns of interaction in EFL classrooms. In The Global Summit on Education (pp. 859-864). Kuala Lumpur:

WorldConferences.net.

Murray, D. E., \& Christison, M. (2011). What English language teachers need to know volume II: Facilitating learning. New York: Taylor \& Fancis e-Libaray. Retrieved from https://doi.org/10.4324/9780203846292.

Nasruloh, M. I. (2013). Teacher-student interaction in a project-based learning classroom. Journal of English and Education, 1(1), 142-153.

Nisa, S. H. (2014). Classroom Interaction analysis in Indonesian EFL speaking class. English Review: Journal of English Education, 2(2), 124-132.

Petek, E. (2013). Teacher's beliefs about classroom interaction and their actual practices: A Qualitative case study of a native and a non-native English teacher's in-class applications. Procedia - Social and Behavioral Sciences, 70, 1195-1199. Retrieved from https://doi.org/10.1016/j.sbspro.2013.01.176.

Pujiastuti, R. T. (2013). Classroom interaction: An 
analysis of teacher talk and student talk in English for Young Learner (EYL). Journal of English and Education, 1(1), 163-172.

Rashidi, N., \& Rafieerad, M. (2010). Analyzing patterns of classroom interaction in EFL classrooms in Iran. Journal of Asia TEFL, 7(3), 93-120.

Richards, J. C., \& Lockhart, C. (2007). Reflective teaching in second language classrooms. USA: Cambridge University Press.

Rido, A. (2017). Questioning strategies of master teachers in Indonesian vocational English classrooms. TEFLIN Journal, 2(28), 193-211.

Rido, A., Ibrahim, N., \& Nambiar, R. M. K. (2014). Investigating EFL master teacher's classroom interaction strategies: A case study in Indonesian Secondary vocational school. Procedia - Social and Behavioral Sciences, 118, 420-424. Retrieved from https://doi.org/10.1016/j.sbspro.2014.02.057.

Robinson, H. A. (2005). The ethnography of empowerment: The transformative power of classroom interaction. London: Taylor \& Fancis eLibaray.

Rustandi, A., \& Mubarok, A. H. (2017). Analysis of IRF (Initiation-Respon-Feedback) on classroom interaction in EFL speaking class. Edulite: Journal of English Education, Literature, and Culture, 2(1), 239-250.
Seedhouse, P., \& Jenks, C. J. (2015). International perspectives on ELT classroom interaction. Hampshire: Palgrave MacMillan.

Sundari, H. (2016). Pengaruh input bahasa orangtua terhadap kompleksitas bahasa anak: Studi kasus pada anak usia 5 tahun melalui interactive shared reading. Jurnal Pendidikan Bahasa Dan Sastra, 16, $110-121$.

Suryati, N. (2015). Classroom Interaction strategies employed by English teachers at lower secondary schools, 247-264. Retrieved from

http://journal.teflin.org/index.php/journal/article/ download/268/252.

Thoms, J. J. (2012). Classroom discourse in foreign language classrooms: A review of the literature. Foreign Language Annals, 45(S1), 8-27. Retrieved from https://doi.org/10.111/j.19449720.2012.01177.x.FOREIGN.

Wachyudi, K., Srisudarso, M., \& Miftakh, F. (2015). Analisis pengelolaan dan interaksi kelas dalam pengajaran Bahasa Inggris. Jurnal Ilmiah Solusi, 1(4), 40-49. Retrieved from https://doi.org/10.1017/CBO9781107415324.004.

Walsh, S. (2011). Exploring classroom discourse: Language in Aaction. Oxon: Routlege Taylor \& Francis Group. 